\title{
REVIEWS
}

Adv Clin Exp Med 2014, 23, 2, 295-298

ISSN 1899-5276

(๑) Copyright by Wroclaw Medical University

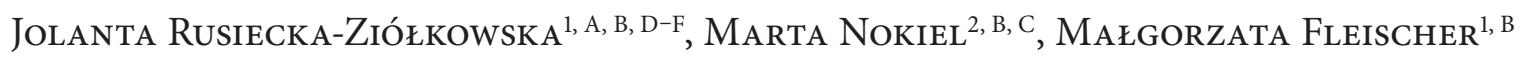

\section{Demodex - An Old Pathogen or a New One?}

${ }^{1}$ Department of Microbiology, Wroclaw Medical University, Poland

2 ALAB Laboratories, Wroclaw, Poland

A - research concept and design; $\mathbf{B}$ - collection and/or assembly of data; C - data analysis and interpretation;

$\mathbf{D}$ - writing the article; $\mathbf{E}$ - critical revision of the article; $\mathbf{F}$ - final approval of article; $\mathbf{G}$ - other

\begin{abstract}
Demodex was first identified over 150 years ago, but only recently has it attracted wider interest as a contributor to chronic diseases such as acne rosacea or marginal blepharitis. Demodex is commonly found in the human population, in skin sebaceous glands or follicles. The frequency of Demodex infection increases with age, as it is mainly diagnosed after the age of seventy; however, it can sometimes be found in children and teenagers. Demodex is supposed to contribute to the development of marginal blepharitis or acne rosacea, but the pathogenic mechanisms have not yet been explained in detail. These diseases are chronic and the long-term treatment effects are not satisfactory. This paper presents the characteristics of Demodex as well as its prevalence in the pathogenesis of eye and skin diseases, and describes the diagnostics and treatment of these disorders (Adv Clin Exp Med 2014, 23, 2, 295-298).
\end{abstract}

Key words: Demodex, pathogenicity, diagnostics, treatment.

In recent years, an increase in Demodex infections has been observed. These microscopic mites, which are commonplace all over the world, were identified in the $19^{\text {th }}$ century, but for years they attracted little scientific interest and were not generally associated with symptoms found in humans. Only a few researchers tried to establish the role Demodex plays in the pathogenesis of human and animal diseases. The first reports discussing Demodex type mites appeared in 1841, authored by Jakub Henle, the professor of anatomy from Zurich. A year later, a German dermatologist named G. Simon found this pathogen in hair follicles. Six years later, Simon published a book with detailed illustrations presenting $D e-$ modex follicuorum [1]. In 1875, Becler described Demodex found in eyelid margins and eyelash follicles, and Majocchini and Burchard detected the organism in tarsal cyst material [2]. The term demodecosis was used for the first time by Ayres in 1961, when human Demodex was found in the pathogenesis of acne rosacea. Two years later, Abkulatowa distinguished another variety of the mites: Demodex brevis. In 1972, Desh and Nutting showed that Demodex folliculorum exists in hair follicles, whereas Demodex brevis was found in the meibomian glands $[3,4]$.

Demodex belongs to the class of arachnids (Arachnida), the scab mites subdivision (Acarida) and the hair follicle mites family (Demodiacidae) The name Demodex comes from the combination of two Greek words: demos (skin) and dex (worm). These mites prevail all over the world and are characterized by a parasitic existence. They occur in mammal hair follicles, sebaceous glands (Zeiss' glands) and eyelid glands (Meibom's glands). They may evoke demodecosis in both humans and animals, the course of which is chronic [5].

The 2 kinds of Demodex mites that have been identified in humans (Demodex folliculorum and Demodex brevis) commonly appear in seborrheic areas of the facial skin (the forehead, chin, and around the eyes and mouth). They are also observed on the pileous skin of the head, on hairy chests or in the genital area $[4,6-8]$.

Demodex appears in dogs too, in the form of Demodexcanis, and may cause severe inflammation of sebaceous glands or hair follicles. The parasites may also penetrate the lymph nodes, liver, spleen and other organs, causing general symptoms and 
death. In such cases they can be found in blood, urine and feces [2].

Demodex occurs in other animals as well, including cats (Demodex cati), cattle (Demodex bovis), goats (Demodex caprae), sheep (Demodex ovis) and rats (Demodex ratti). These kinds are pathogenic for animals only and are not found in humans [5].

Demodex mites are white or yellow in color, and have an elongated oval shape that narrows towards the rear. Demodex individual have 4 pairs of prolegs on their front section (Fig. 1).

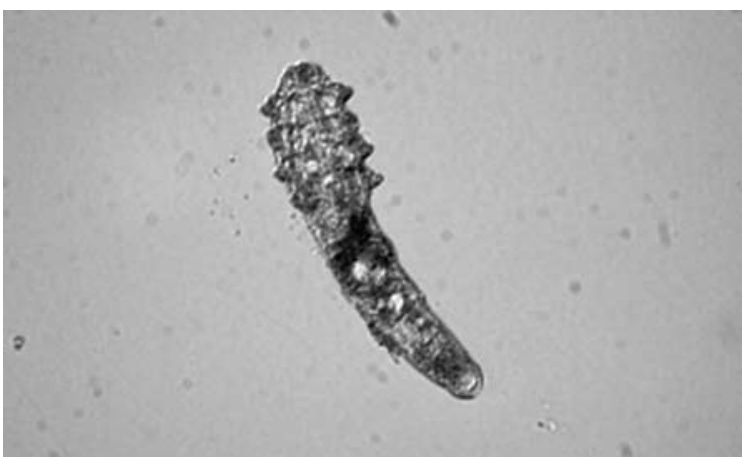

Fig. 1. Demodex mature form - authors' own observations

The mites' developmental cycle lasts 3-4 weeks and takes place in one host. Larvae with 3 pairs of prolegs hatch out of eggs; after molting, nymphs with four pairs of prolegs are formed, eventually changing into adult males and females after 2 molts. Demodex folliculorum is $300-400 \mu \mathrm{m}$ long, while Demodex brevis is $250-280 \mu \mathrm{m}$ long; their width is similar: 40-45 $\mu \mathrm{m}[5,9]$. Demodex mites feed on sebum, lymph, plasma and epithelial cells. In humid environments, adult mites can survive for 3 weeks whereas dry conditions cause them to die in $36 \mathrm{~h} \mathrm{[9].}$

D. folliculorum mites live in hair follicles or sebaceous glands. They occur in concentrations and the disease progresses as the patient's age increases. In turn, D. brevis is usually located in the meibomian glands; it is found to live individually and morbidity is not age dependent [4].

\section{Epidemiology}

Demodex occurs all over the world in almost all human races, including various ethnic groups such as Aborigines and Eskimos. About $80-90 \%$ of the human population is infected with Demodex; however, $D$. folliculorum is more often found in females than in males [6]. According to some studies, it more frequently causes face lesions in middle-aged women who often use makeup remover liquids instead of soap [6].
Demodex infections frequency increase with age; the mites are commonly detected in people over 70 years of age and rarely detected in children and teenagers, which may be caused by the fact that the activity of the glands of Zeiss and the meibomian glands diminishes with age [5]. Some researchers claim that immunological disturbances may favor Demodex infections in children [5, 10]; the mites have been observed especially in children with leukemia and with chronic blepharitis $[5,11]$.

Demodex infection may be the result of direct contact with an infected person's skin, or indirectly through contact with contaminated objects such as towels, combs, blankets, sponges or bed clothing.

\section{Eye Diseases}

Demodex is considered to play a role in the pathogenesis of eye diseases by causing chronic blepharitis. The mites' presence in hair follicles causes inflammatory processes in the tissues and damages hair bulbs, which may cause a loss of eyelashes surrounded by cylindrical dandruff. Enlarged blood vessels are visible on the eyelid rims. Demodex is supposed to be the vector for a number of antigens also bacterial and mycotic additionally favoured by lacrimal film $\mathrm{pH}$ changes. Antigens penetration to conjuctivitis epithelium superficial layers provokes an immunological response in the form of antigen presenting cells, lymphocytes and Langerhans' cells, as well as the secretion of proinflammatory cytokins. In ophthalmic demodecosis, examinations of the eye conjunctiva reveal elevated levels of macrophages and CD4 lymphocytes, and the interleukin-1 level was increased in the lacrimal film [12].

Demodex folliculorum is considered to induce the humoral response from IgM and IgG production, whereas Demodex brevis is responsible for the cellular response [13].

Demodex is rarely considered an etiological agent in inflammation of the palpebral margins. Due to the number of possible reasons for this disorder, bacterial or mycotic infections, allergy or refractive error are taken into account more often [5]. In the majority of cases, the course of the disease is completely asymptomatic and only sometimes slight itching is observed. Demodex may also cause severe inflammation of the palpebral margins. Patients complain of a burning sensation in the eyes, lacrimation and hypersensitivity to light, dust and smoke. The eyelid margins become reddened and there is a deficiency of the lipid layer of the lacrimal film. A chronic condition may result in eyebrow and eyelash loss, inflammatory edema 
of the eyelids and conjunctiva, as well as secondary bacterial infections $[14,15]$. In cases of severe inflammation of the palpebral margins, microscopic examinations revealed as many as 12 full-grown Demodex individuals on one eyelash. [11].

\section{Skin Diseases}

The role of Demodex in the pathogenesis of skin disorders in adult patients has been widely discussed. Only increased numbers of the mites - more than 5 individuals on $1 \mathrm{~cm}^{2}$ of skin - are closely associated with pathogenic activity $[7,16]$. Demodex may cause a number of lesions in human skin. The mites have been found in patients suffering from papular and papulopustular rosacea, perioral dermatitis and hair folliculitis [4].

Acne rosacea is a chronic disease, located mainly on the face, in which vascular and seborrheic lesions constitute the basis for the development of the illness. It is more often diagnosed in women with fair complexions. A number of factors are responsible for acne rosacea: genetics, hormones, environmental influences, diet or Demodex folliculorum infections [17].

The symptoms of acne rosacea appear in the central part of the face (the forehead, cheeks, nose and chin), and they are recurrent. The primary symptoms have been defined as paroxysmal erythema, pimples, papules and telangiectasias. Secondary symptoms have also been observed: edema, skin dryness, ophthalmic lesions and hypertrophic changes. The role of Demodex in the development of acne rosacea can be the blockage of hair follicles, the stimulation of inflammatory reactions or superficial transmission of Flavobacterium spp. and Bacteroides spp. [3, 18, 19]. Along with the presence of Demodex, immunohistological tests show proliferations of accessory $T$ lymphocytes, plasmocytes, histocytes and giant cells. This may indicate the development of a cellular type response $[3,4,20]$.

\section{Diagnosing Demodecosis}

Diagnosing demodecosis can pose some problems, since Demodex is an obligate parasite. Both clinical symptoms and the presence of increased numbers of Demodex organisms in lesions are taken into account. The following methods are used in demodecosis diagnostics:

1. Direct eyelash section: after epilation of the upper and lower eyelids, prepared specimens are placed on microscopic slides in dimethylosulphoxide (DMSO) solution or $10 \%$ potassium hydroxide.
The specimens are studied at $200 \times$ magnification. The presence of mature Demodex folliculorum individuals in the specimens and the form of larvae or chitin exuviae is the evidence of Demodex infestation.

2. Direct epidermis preparation: scrapings from diseased epidermis, papules and pimple secretions are placed in a $20 \%$ solution of potassium oxide $(\mathrm{KOH})$ and inspected under light microscope.

3. Standardized skin surface biopsy: this method allows the number of mites to be estimated. A slide covered with glue with cyanoacrylate and a marked square $1.03 \mathrm{~cm}^{2}$ in size is pressed against the skin surface. After $30 \mathrm{~s}$, the slide is removed and the material stratum with hair follicles - is elicited. The preparation is inspected with the use of a light microscope at $40 \times$ and $100 \times$ magnification and the number of live mites per $1 \mathrm{~cm}^{2}$ can be assessed. The time interval between harvesting the material and evaluating the specimen cannot exceed $4 \mathrm{~h}[4,16]$.

4. Skin biopsy: histologic examination of a skin sample stained with hematoxilin and eosin. This method provides a small amount of material and hair follicles cannot be assessed [4, 7].

The presence of Demodex mites in a specimen is not equivalent to a diagnosis of demodecosis. As noted above, the results are considered positive when the number of mites exceeds 5 individuals in $1 \mathrm{~cm}^{2}$ of skin surface. Interpreting the examination results may be difficult, as Demodex mites often occur in skin lesions with other etiological agents that can impede a correct diagnosis. Differential diagnostics should be carried out, taking both the test results and the clinical symptoms into account.

\section{Treatment}

The treatment of diseases caused by Demodex mites is difficult and may last for several months. In the case of inflammations of the palpebral margins, local application of sulphuric ointment, yellow mercuric ointment, anticholinesterase, antifungal drugs or antibiotics have been noted to cause clinical improvement; the best results were elicited after the application of metronidazole, mercuric and erythromycin ointments [2, 21, 22]. At the same time, eyelid margin hygiene should be maintained with diluted tea tree extract shampoo, as well as rinsing the face with delicate soap to decrease the danger of mite infestation. The use of $4 \%$ pilocarpine gel brought about complete healing in $37.5 \%$ of cases, and partial cure in $40.6 \%$ of cases [23]. Alternatively, minocycline can be administered for 6 months [2]. Good results have been achieved with medication consisting of onion and chamomile extracts, heparin and alantoin. After 
the treatment, improvement in the clinical condition of the eyelid margins was observed, as well as a reduction in the number of mites [24].

The treatment of acne rosacea in which Demodex spp. play a pathogenic role is based on oral use of metronidazole and ivermectin as well as local use of lindane cream, crotamiton and permethrin [11].

Demodex was discovered over 150 years ago. However, for years was not the subject of investigations, due to insufficient knowledge concerning this parasite's part in chronic and severe diseases such as inflammation of the eyelid margins or acne rosacea, and its influence on the exacerbation of other diseases. It is only recently that studies of Demodex have contributed to the development of methods that enable proper diagnosis and treatment of the dermatological and ophthalmological disorders.

\section{References}

[1] Schaller M, Sander Ch, Plewig G: Demodex abscesses: Clinica and therapeutic challenges. J Am Acad of Dermatol 2003, 49, 272-274.

[2] Gerkowicz M, Baltaziak L, Puacz E: Przewlekłe zapalenie brzegów powiek. Klin Oczna 2005, 107, 376-378.

[3] Borowska K, Antiszko M, Zabielski S: Etiopatogeneza tradzika różowatego ze szczególnym uwzględnieniem roztoczy z rodzaju Demodex. Lek Woj 2003, 79, 235-238.

[4] Bohdanowicz D, Raszeja-Kotelba B: Demodex w etiopatogenezie niektórych chorób skóry. Post Dermatol Alergol 2001, 8, 51-58.

[5] Czepita D, Kuźnia-Grygiel W, Kosik-Bogacka D: Badania nad występowaniem oraz rolą Demodex folliculorum i Demodex brevis w patogenezie przewlekłego zapalenia powiek Klin Oczna 2005, 107, 80-82.

[6] Raszeja-Kotelba B, Jenerowicz D, Izdebska JN, Bowszyc-Dmochowska M, Tomczak M, Dembińska M: Niektóre aspekty zakażenia skóry nużeńcem ludzkim. Wiad Parazytol 2004, 50, 41-54.

[7] Wesołowska M, Baran W, Szepietowski J, Hirschberg L, Jankowski S: Demodekoza u ludzi jako aktualny problem w dermatologii. Wiad Parazytol 2005, 51, 253-256.

[8] Nath AK, Timshina DK, Thappa DM, Sinclair R: Demodex in an aerobic environment on the eyelashes. Australas J Dermatol 2012, 53, 159-160.

[9] Larios G, Alevizos A, perimeni D, Rigopoulos D, Katsambas A: Rosacea-like demodicidosis. Lancet Infect Dis 2008, 8, 804 .

[10] Kuźna-Grygiel W, Kosik-Bogacka D, Czepita D, Sambor I: Objawowe i bezobjawowe inwazje Demodex spp. Powiek u osób w różnych grupach wiekowych. Wiad Parazytol 2004, 50, 55-61.

[11] Damian D, Rogers M: Demodex infestation in a child with lekaemia: treatment with ivermectin and permethrin. Int J Dermatol 2003, 42, 724-726.

[12] Kim JT, Lee SH, Chun YS, Kim JCh: Tear cytokines and chemokines in patients with Demodex blepharitis. Cytokine 2011, 53, 94-99.

[13] Raszeja-Kotelba B, Pecold K, Pecold-Stępniewska H: Oczny trądzik różowaty - aktualne dane etiopatogenetyczne, kliniczne i terapeutyczne oraz opis trzech przypadków. Post Derm i Alergol 2004, 21, 144-150.

[14] Czepita D: Demodekoza powiek. Lekarz 2008, 1-2, 23-27.

[15] Sarro R, Hong JJ, Elgart ML: An unusual demodicidosis manifestation in a patient with AIDS. J Am Acad Dermatol 1998, 38, 1, 120-121.

[16] Askin U, Seckin D: Comparision of the two techniques for measurement of the density of Demodex folliculorum: standardized skin surface biopsy and direct microscopic examination. Br J Dermatol 2010, 162, 1124-1126.

[17] Basta-Juzbašić A, Škrlin-Šubić J, Ljubojević S: Demodex folliculorum in development of dermatitis rosaceiformis steroidica and rosacea-related diseases. Clin Dermatol 2002, 20, 135-140.

[18] Burroughs R, Maggio K: Electronmicroscopic investigation into the possible etiology of rosacea and the implication for treatment. J Am Acad Dermatol 2007, 56, 2, 44.

[19] Jarmuda S, O’Reilly N, Zaba R, Jakubowicz O, Szaradkiewicz A, Kavanagh K: Potential role of Demodex mites and bacteria in the induction of rosacea. J Med Microbiol 2012, 61, 1504-1510.

[20] Dhingra KK, Saroha V, Gupta P, Khurana N: Demodex-associated dermatologic conditions - A coincidence or anetiologicalcorrelate. Review with a report of a rare case of sebaceous adenoma. Pathol Res Pract 2009, 205, 423-426.

[21] Junk AK, Lukacs A, Kampik A: Topical administration of metronidazole gel as an effective therapy alternative in chronic Demodex blepharitis - case report. Klin Monatsbl Augenheilkd 1998, 213, 48-50.

[22] Rodriguez AE, Ferrer C, AliŏJ L: Chronic blepharitis and Demodex. Arch Soc Esp Oftalmol 2005, 80, 635-642.

[23] Inceboz T, Yaman A, Over L, Ozturk AK, Akisu C: Diagnosis and treatment of demodectic blepharitis. Turkiye Parazitol Derg 2009, 33, 32-36.

[24] Stożkowska W, Raczyńska K: Skuteczność i bezpieczeństwo stosowania preparatu Cepan. Obserwacja nowego wskazania. Przegl Lek 2008, 65, 5, 241-243.

\section{Address for correspondence:}

Jolanta Rusiecka-Ziółkowska

Department of Microbiology

Wroclaw Medical University Conflict of interest: None declared

Chałubińskiego 4

50-368 Wroclaw

Poland

Received: 30.06 .2012

E-mail: jolanta.rusiecka-ziolkowska@am.wroc.pl 